\title{
Evaluation of functional changes in the evolutionary stages of Parkinson's disease: a case series
}

\author{
Avaliação das alterações funcionais nos estágios evolutivos \\ da doença de Parkinson: uma série de casos
}

\section{Natália Feitoza do Nascimento, Dominique Babini Lapa de Albuquerque*}

Faculdade de Comunicação, Tecnologia e Turismo de Olinda (FACOTTUR), Olinda, PE, Brazil

\begin{abstract}
Introduction: Parkinson's disease is one of the fastest growing neurological disorders in the world and is considered to be predominantly a motor disorder, classified as neurodegenerative, chronic and extrapyramidal, characterized by tremors, muscular rigidity, postural balance deficit and bradykinesia. Objective: To analyze the functional changes presented by Parkinson's disease patients in the different evolutionary stages of the disease. Methods: The sample included 30 patients of both genders, aged between 51 and 75 years, with clinical diagnoses of Parkinson's disease in different evolutionary stages, undergoing physiotherapy in the Pernambuco Parkinson Association. The patients were evaluated through the Hoehn and Yahr Staging Scale and the Unified Parkinson's Disease Rating Scale (UPDRS). Results: The results highlighted an increase in the presence and severity of the changes presented by the Parkinson's disease patients, according to the evolution of the stages of the disease, especially considering aspects relating to motor activity and activities of daily living, including changes related to speech, swallowing, the ability to get dressed, personal hygiene, turning in bed and arising from a chair, occurrence of falls, posture, gait, postural stability and the presence of bradykinesia/hypokinesia. Conclusion: It is believed that the classification of the evolutionary
\end{abstract}

* NFN: MSc, e-mail: nataliafna@yahoo.com.br

DBLA: MSc, e-mail: dbabini.fisioterapeuta@gmail.com 
stage of patients through the Hoehn and Yahr Scale and the registration of functional change through the UPDRS are useful for the development of the physiotherapy treatment plan.

Keywords: Parkinson's Disease. Evaluation. Physiotherapy.

\section{Resumo}

Introdução: A Doença de Parkinson é um dos distúrbios neurológicos que mais cresce no mundo, sendo considerada uma afecção neurodegenerativa, extrapiramidal e crônica, predominantemente motora, caracterizada por tremor, rigidez muscular, déficit de equilíbrio postural e bradicinesia. Objetivo: Analisar as alterações funcionais apresentadas pelos portadores da Doença de Parkinson nos diferentes estágios evolutivos da patologia. Métodos: Fizeram parte da amostra 30 pacientes com diagnóstico clínico da Doença de Parkinson, nos diversos estágios evolutivos da doença em tratamento fisioterapêutico na Associação de Parkinson de Pernambuco de ambos os gêneros, na faixa etária entre 51 e 75 anos. Os pacientes foram avaliados através da Escala de Estadiamento de Hoehn e Yahr e Escala Unificada de Avaliação da Doença de Parkinson (UPDRS).

Resultados: Os resultados apontam para o aumento da presença e gravidade das alterações apresentadas pelos portadores da Doença de Parkinson, segundo a evolução dos estágios da patologia, principalmente considerando os aspectos referentes à atividade motora e atividades de vida diária, com destaque para as alterações relacionadas à fala, à deglutição, à capacidade de vestir-se, higienizar-se, girar no leito e levantar-se da cadeira, à ocorrência de quedas, à postura, estabilidade postural e marcha, e à presença de bradicinesia/ hipocinesia. Conclusão: Acredita-se que a classificação do estágio evolutivo dos pacientes através da Escala Hoehn e Yahr e os registros das alterações funcionais através da Escala UPDRS sejam úteis para a elaboração de plano de tratamento fisioterapêutico.

Palavras-chave: Doença de Parkinson. Avaliação. Fisioterapia.

\section{Introduction}

Parkinson's disease is one of the fastest growing neurological disorders in the world, ranking second among these, and mainly affects individuals of advanced age. In Brazil, there has been a significant increase in the elderly population and probably an increase in Parkinson's disease cases (1). The disease presents an average prevalence of $1 \%$ of the worldwide elderly population (2) with a slight predominance in males. After 75 years of age, the prevalence is 1 in every 100 people (1).

The epidemiological incidence is high, with it being considered the most common movement disorder in the world and the third most common chronic disease of advanced age groups, after the cerebrovascular diseases and rheumatoid arthritis (3). With increasing life expectancy, it is estimated that 10 million people worldwide are currently living with Parkinson's disease. It is expected that this number will double by 2030 (4).
Parkinson's disease generates severe disability after 10 to 15 years of manifestation and the social and financial impact is high, particularly in the older population. It is estimated that the annual global cost of antiparkinson agents is around $\$ 11$ billion (5). Therefore, it causes an impact in the economic structures, since it affects both females and males of all social classes and races (6). This fact highlights the disease as a public health concern.

Parkinson's disease affects the voluntary and automatic movements, due to dysfunction of the basal ganglia. The central biochemical syndrome of the pathology results from the reduction of neurotransmission in the basal ganglia, generated by the marked loss of dopamine content in the striatum (7). The cause of this dysfunction is the death of the dopamine-producing cells in the compact part of the substantia nigra and the acetylcholine-producing cells in the pedunculopontine nucleus (8).

Several factors may be triggering agents for the disease, such as: genetics, atherosclerosis, excessive 
accumulation of oxygen free radicals, viral infections, head trauma, use of antipsychotic medications and environmental factors (9).

Parkinson's disease is considered to be predominantly a motor disorder, classified as neurodegenerative, chronic and extrapyramidal, and is clinically characterized by tremors, muscular rigidity, postural balance deficit and bradykinesia (10).

The tremors are caused by disinhibition of the agonist muscles and inhibition of the antagonist muscles (11). Muscular rigidity is caused by hypertension in all muscle groups. The atrophy and degeneration of the basal ganglia generate an exacerbated inhibitory pattern, causing the patient to have difficulty in modulating balance strategies (12). Bradykinesia corresponds to a slowness of movement, especially the automatic movements (13). Flexed posture and freezing phenomenon are characteristic of the disease (14).

Other changes characteristic of the disease are hypomimia, decreased blink rate and hypophonia, decreased arm swing and the tendency for the foot of the more affected side to drag, micrographic changes, deficit in saliva swallowing and the presence of sialorrhoea (15). Pain often results from a lack of mobility in the affected limbs, with shoulder pain being a common complaint (16).

There is no specific test or set of tests used to diagnose Parkinson's disease; the diagnosis is made based on the history of the patient and a clinical examination (17). Thus, the disease is established with the presence of two of the major signs (18), described as: muscle rigidity, postural balance deficit and bradykinesia (19).

Providing patients with speech therapy and physiotherapy, among others, should be associated with the medical treatment (20). The rehabilitation of Parkinson's disease patients is especially directed towards the motor limitations, requiring a functional assessment to identify the dysfunctions and establish a targeted treatment program (21).

Physiotherapists have an important body of knowledge related to the identification, treatment and prevention of movement disorders. However, standardized evaluation instruments for Parkinson's disease are not commonly used. It is important for the therapist to determine in advance the data needed to describe the degree of performance and skills in activities (22).
In order to better evaluate the clinical and functional status of the patient, as an aid for future therapeutic interventions, the Hoehn and Yahr scale (Hoehn and Yahr Staging Scale) and the UPDRS (Unified Parkinson's Disease Rating Scale) stand out, which may be used by physiotherapists due to their high reliability (23).

The Hoehn and Yahr Scale is an assessment instrument that allows the classification of the individual regarding the stage of impairment in Parkinson's disease and is able to quickly and efficiently indicate the general stage (24). The UPDRS evaluates the signs, symptoms and certain activities of the patient through the self report of the patient and clinical observation. It is widely applied as it evaluates both motor function and activities of daily living (25).

This study aimed to analyze the functional changes presented by Parkinson's disease patients at different evolutionary stages of the disease, in order to contribute to greater knowledge regarding the clinical presentation of the disease and thus facilitate the development of a specific treatment plan for each patient.

\section{Materials and methods}

This was a prospective, analytical and quantitative study, of the case series type. The sample included 30 patients of both genders, aged between 51 and 75 years, with a mean age of 68.19 years, clinical diagnosis of Parkinson's disease in different evolutionary stages, undergoing physiotherapy in the Pernambuco Parkinson Association. Six Parkinson's disease patients were selected for each of the stages, 1, 2, 3, 4 and 5, of the Hoehn and Yahr scale.

Patients with other neurological disorders were excluded from the study, as were those that showed any sort of fatigue, discomfort and/or blood pressure less than $160 \times 90 \mathrm{mmHg}$ at rest, during the evaluation.

Initially, the Parkinson's disease patients of the Pernambuco Parkinson Association were invited by the researcher to participate in the study through a letter of invitation covering the aims of the study and its scientific relevance. Subsequently, those patients that accepted the invitation were evaluated using the Hoehn and Yahr Scale and were classified according to the Parkinson's disease evolutionary stage. 
Next, the study participants underwent a second evaluation using the UPDRS, which consists of 42 items with scores ranging from 0 (normal) to 4 (highest level of disability), arranged in four criteria: mental activity and behavior; activities of daily living (ADLs); motor function; and complications of the pharmaceutical therapy (22). This scale allowed the registration of the Parkinson's disease signs and symptoms presented by the participants, with it being possible to observe the functional changes at each stage of the disease.

Data were evaluated using analytical statistics, through percentages, means and standard deviations, represented by tabular and graphical distribution, with $\mathrm{p}<05$ considered as the level of statistical significance.

\section{Results}

In the study it was found that 18 patients were male, accounting for $60 \%$ of the sample, and $40 \%$ female, as shown in Table 1, in which the prevalence of the patients in each stage by gender and mean age can also be observed.

There was an increase in the mean general scores obtained by the patients of the sample through the UPDRS according to the evolution of the Parkinson's disease stages (Figure 1). According to the study, the score rose in each stage due to the rise in the score in the UPDRS and demonstrates the increased dysfunction of the patients, particularly in stages 4 and 5 , signifying a large functional loss for the individuals in these latter stages. The application of the Student's T-test showed statistically significant differences between the variables in all the evolutionary stages of the disease, which indicates these to be dependent variables.

The mean score of each of the four criteria evaluated by the UPDRS increased in the majority of the Parkinson's disease evolutionary stages, with statistically significant differences being registered through the Student's t-test for all analyzed aspects of the ADLs and Motor Examination criteria (Table 2). This characterized a relationship between the stages and the impairments in the study.

The activities of daily living and motor examination criteria of this scale obtained total scores of 52 and 56, respectively, and each item that constitutes these criteria was analyzed in order to quantify and qualify the interference in the daily activities and motor difficulties presented by the patients.

The mean scores for each item of the ADLs criterion are presented in Table 3, which shows an increase in the majority of the mean scores of the 13 items of the ADLs criteria in the evolution from one stage to the next (Table 3). There were statistically significant differences between stages 1 and 5 for the following items: speech, swallowing, dressing, hygiene, turning in bed, falls, and gait.

The mean scores for each item of the Motor Examination criterion are presented in Table 4, with statistically significant differences recorded between stages 1 and 5 for the following items: speech, arising from chair, posture, gait, postural instability, and bradykinesia/hypokinesia. An increase in mean scores was verified in the majority of the 14 items of the Motor Examination criterion in the evolution from one stage to the next (Table 4).

Table 1 - Distribution of gender and age of the patients according to Parkinson's disease evolutionary stage

\begin{tabular}{ccccc}
\hline Stage & \multicolumn{2}{c}{ Gender } & \multicolumn{2}{c}{ Age } \\
\hline & Male & Female & Mean & Age group \\
2 & $66.6 \%$ & $33.4 \%$ & 62.33 & $51-70$ years \\
3 & $66.6 \%$ & $33.4 \%$ & 66.66 & $58-75$ years \\
4 & $66.6 \%$ & $33.4 \%$ & 66.66 & $61-71$ years \\
5 & $50.0 \%$ & $50.0 \%$ & 72.66 & $69-75$ years \\
Total & $50.0 \%$ & $50.0 \%$ & 74.33 & $73-75$ years \\
\hline
\end{tabular}

Source: Applied scale (2011). 


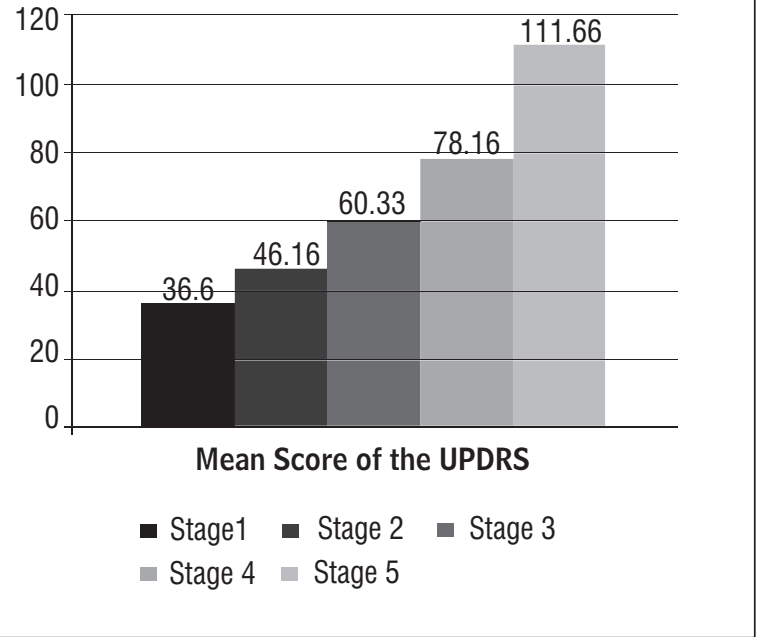

Figure 1- Graphical distribution of mean general scores according to Parkinson's disease evolutionary stage

\section{Discussion}

According to the study and corroborating the literature, men are more affected than women, usually in the ratio of 2:1 (23).

The prevalence of Parkinson's disease increases with age and usually affects individuals over 50 years of age (25). It is considered by many to be an abnormal acceleration of aging, because in most cases the symptoms begin between 55 and 65 years of age (25).

Stage 1 is characterized by complete functionality, with the patient presenting unilateral tremor and rigidity. The intermediate or moderate stage consists of bilateral symptoms, including bradykinesia, rigidity and changes in posture and gait. In the late or severe stage, the patient is intensely impaired and dependent in activities of daily living (4).

Table 2 - Distribution of the mean score for each criterion evaluated by the UPDRS according to Parkinson's disease developmental stage

\begin{tabular}{lccccc}
\hline \multirow{2}{*}{ UPDRS criteria } & \multicolumn{5}{c}{ Stages } \\
\cline { 2 - 6 } & $\mathbf{1}$ & $\mathbf{2}$ & $\mathbf{3}$ & $\mathbf{4}$ & $\mathbf{5}$ \\
\hline Mental State & 4.5 & 4.5 & 5.83 & 6.33 & 8.33 \\
ADLs $^{1}$ & 9.16 & 16.16 & 18.33 & 27.83 & 39.66 \\
Motor examination $^{2}$ & 17.83 & 19.66 & 27.00 & 35.66 & 48.00 \\
$\begin{array}{l}\text { Complications of Pharmaceutical } \\
\text { Therapy }\end{array}$ & 5.66 & 7.66 & 9.16 & 9.16 & 12.33 \\
\hline
\end{tabular}

Source: Applied scales (2011).

Table 3 - Distribution of the mean score for each item of the ADLs criterion evaluated by the UPDRS according to Parkinson's disease developmental stage

(to be continued)

\begin{tabular}{lccccc}
\hline & ADLs & \multicolumn{5}{c}{ Stages } \\
\cline { 2 - 6 } & $\mathbf{1}$ & $\mathbf{2}$ & $\mathbf{3}$ & $\mathbf{4}$ & $\mathbf{5}$ \\
\hline Speech $^{1}$ & 0.66 & 1.00 & 1.16 & 1.66 & 3.00 \\
Salivation & 0.50 & 1.66 & 2.00 & 2.16 & 2.16 \\
Swallowing $^{2}$ & 0.00 & 1.33 & 1.33 & 1.83 & 3.16 \\
Writing & 1.33 & 2.00 & 2.00 & 2.83 & 3.33 \\
Cutting/Handling food $_{\text {Dressing }}$ & 1.33 & 1.83 & 1.66 & 2.50 & 3.33 \\
Hygiene $^{4}$ & 0.16 & 0.66 & 1.00 & 2.16 & 3.50 \\
& 0.16 & 0.83 & 0.66 & 1.66 & 3.00
\end{tabular}


Table 3 - Distribution of the mean score for each item of the ADLs criterion evaluated by the UPDRS according to Parkinson's disease developmental stage

(conclusion)

\begin{tabular}{lccccc}
\hline & \multicolumn{5}{c}{ Stages } \\
\cline { 2 - 5 } & $\mathbf{1}$ & $\mathbf{2}$ & $\mathbf{3}$ & $\mathbf{4}$ & $\mathbf{5}$ \\
\hline Turning in bed $^{5}$ & 0.00 & 0.50 & 1.50 & 1.66 & 3.00 \\
Falls $^{6}$ & 0.66 & 0.66 & 1.33 & 2.33 & 3.16 \\
Freezing & 1.16 & 1.16 & 1.50 & 2.66 & 3.50 \\
Gait7 & 1.00 & 1.16 & 1.50 & 2.33 & 3.66 \\
Tremors & 1.33 & 1.83 & 2.16 & 3.16 & 3.16 \\
Sensory complaints & 1.00 & 1.33 & 1.00 & 2.00 & 3.00 \\
\hline
\end{tabular}

Source: Applied scales (2011).

Table 4 - Distribution of the mean score for each item of the Motor Examination criterion evaluated by the UPDRS according to Parkinson's disease developmental stage

\begin{tabular}{|c|c|c|c|c|c|}
\hline \multirow{2}{*}{ Motor Examination } & \multicolumn{5}{|c|}{ Stages } \\
\hline & 1 & 2 & 3 & 4 & 5 \\
\hline Speech $^{1}$ & 0.50 & 1.16 & 1.33 & 1.66 & 3.00 \\
\hline Facial Expression & 1.50 & 1.66 & 1.83 & 2.66 & 2.16 \\
\hline Tremor at rest & 1.50 & 1.66 & 2.16 & 2.83 & 3.16 \\
\hline Postural Tremor & 1.33 & 1.33 & 1.50 & 2.33 & 2.50 \\
\hline Rigidity & 1.00 & 1.50 & 1.83 & 2.00 & 3.16 \\
\hline Finger Taps & 1.50 & 1.66 & 2.33 & 2.66 & 3.33 \\
\hline Hand movements & 1.66 & 1.83 & 2.16 & 2.83 & 3.66 \\
\hline Rapid alternating movements & 1.66 & 1.50 & 2.33 & 2.83 & 3.83 \\
\hline Leg agility & 1.66 & 2.16 & 2.66 & 2.83 & 3.66 \\
\hline Arising from char ${ }^{2}$ & 0.00 & 0.33 & 1.33 & 2.33 & 4.00 \\
\hline Posture $^{3}$ & 1.16 & 1.16 & 1.83 & 2.33 & 3.83 \\
\hline Gait" & 1.16 & 1.00 & 1.83 & 2.50 & 4.00 \\
\hline Postural stability ${ }^{5}$ & 0.83 & 0.83 & 1.66 & 2.50 & 3.83 \\
\hline Bradykinesia and Hypokinesia ${ }^{6}$ & 1.33 & 1.66 & 2.50 & 2.66 & 4.00 \\
\hline
\end{tabular}

Source: Applied scales (2011). 
Deficits become evident in performing activities in general, from simple everyday tasks to the planning of more elaborate functions. Added to this, the motivational decline in the patients interferes with the implementation of these activities as they progress through the evolutionary stages of the disease.

Souza, Barreto and Santos (2010) refer to the validity and reliability $(r=0.96)$ of the UPDRS in their study, considering it to be a suitable evaluation method to be applied with Parkinson's disease.

In the ADLs criterion of the UPDRS shown in Table 3, the speech deficit, slightly affected in stage 1 , creates an inability to effectively communicate, which can result in isolation, sadness, depression or hostile behavior directed towards others, particularly in stages 4 and 5 (27).

Swallowing is a frequent complaint from stage 2 due to the inability to perform the rapid and coordinated movements involved in this process. Due to muscle rigidity and bradykinesia, dysphagic manifestations may be caused by the delay in the swallowing reflex and the reduced mobility of the oropharyngeal structures (28).

Issues relating to dressing and hygiene become prevalent from stage 3 , due to the difficulty in righting and balance reactions, which affects daily living activities, especially those that require staying in the standing posture for longer periods, such as showering (29).

As the clinical signs of the disease impact on the motor skills and independence (30), from stage 2 the ability to turn in bed is changed, since the patient that is unilaterally affected can still present adequate mobility when lying down.

Falls are discreetly present in the early stages, however become frequent from stage 3, due to marked postural instability and freezing. Falls are responsible for the increased incidence of subdural hematomas and fractures of the hip, femur and wrist, which often lead to hospitalization and severe functional impairments (31).

Regarding gait, increased difficulty in walking is verified as the disease evolves, from slight difficulty with reduced mobility of the arms to the need for assistance for movement in stage 4 and the inability to walk, even with assistance, in stage 5. Slowness of the gait can also be due to the loss of coordination between pelvic and thoracic rotation, characterizing trunk rigidity (4).
In the motor examination of the UPDRS, shown in Table 4, speech presents a certain impairment from the beginning of the disease, with volume and/or diction loss, which increases in severity with the evolution of the disease stages. Voice disorders are due to three main factors: restrictions in the modulation of the frequency and intensity, reduced intensity, and changes in the quality (32). In stage 4 and 5, it becomes difficult or even impossible to understand what is said by the patients.

In the item arising from the chair, difficulty in performing this task is found from stage 2 . This motor process is regulated by complex cortical mechanisms that may be affected in the mild and moderate stages of the disease, predisposing the patient to the risk of falls (12). Some individuals of stage 4 and all of stage 5 did not perform this test due to the inability to arise without assistance.

Postural changes were recorded in the patients, who adopted kyphosis, an exaggerated forward curvature, inclined or not toward one side. Changes in balance can occur due to any failure in one or more of the systems, causing the individual to complain of body imbalance (33).

Changes in the gait were observed in the patients, with them increasing the number of steps per minute, causing parkinsonian or festinating gait. Patients find it difficult to start and carry out a movement, however, can improve this when there are positive external stimuli (30).

Postural instability is due to bilateral involvement of the disease, this being characteristic from stage 2 of the disease. The classic posture of flexion of the head, thoracic kyphosis, protraction and abduction of the shoulder and flexion of the arms can have negative effects on respiratory function and phonation (34).

Bradykinesia/hypokinesia is a symptom that occurs from stage 1 among Parkinson's disease patients, evolving in each stage and manifesting itself as a reduction in active movement and an absence of automatic movement, including facial expression and normal balance of arms in walking (35).

\section{Conclusion}

From the analysis of the results, it is believed that the classification of the evolutionary stage of Parkinson's disease patients using the Hoehn and 
Yahr Scale and registration of functional changes through the UPDRS are useful for the development of physiotherapy treatment plans specific for each stage of this disease, thus suggesting the importance of knowledge about the clinical presentation of the evolutionary stages of the disease for the therapeutic intervention to be effective.

As this is a neurodegenerative disease, it is essential to have a neurofunctional evaluation, part of this being the application of scales directed toward the various aspects involved in this pathology. The use of these instruments in the evaluation of Parkinson's disease patients allows the designation of the levels of evolution of the disease, which can affect a change or maintenance of the therapeutic plan.

From this study, it is suggested that further studies should address the development of physiotherapy treatment protocols directed toward the different functional manifestations in the different evolutionary stages of the disease.

\section{References}

1. Medeiros J, Júnior LA, Costa MLG, Barros ALC, Costa EG, Costa EG, et al. Avaliação da função executiva em sujeitos portadores de doença de Parkinson no estágio III da escala de Hoehn \& Yahr comparados com grupo controle. Rev Neurobiologia. 2010;73(1):99-106.

2. Hellmann-Regen J, Piber D, Hinkelmann K, Gold SM, Heesen C, Spitzer C, et al. Depressive syndromes in neurological disorders. Eur Arch Psychiatry Clin Neurosci. 2013;263(2):123-36.

3. Nicke R, Pinto LM, Lima AP, Navarro EJ, Teive HAG, Becker N, et al. Estudo descritivo do desempenho ocupacional do sujeito com doença de Parkinson: o uso da CIF como ferramenta para classificação da atividade e participação. Rev Acta Fisiatr. 2010;17(1):13-7.

4. King LA, et al. Comorbidity and functional mobility in persons with Parkinson's disease. Arch Phys Med Rehabil. 2014;95(11):2152-7.

5. BRASIL. Ministério da Saúde. Consulta Pública 02/ 2010. [Cited in 2010 Aug 26]. Available from: http:// tinyurl.com/qhhdx8o

6. Stdeil EMS. Doença de Parkinson: revisão bibliográfica. Disc Scientia. Série: Ciências da Saúde. 2007; 8(1):115-29.
7. Merrit LP, Rowland MD. Tratado de Neurologia. $11^{\text {th }}$ ed. Rio de Janeiro: Guanabara Koogan; 2007.

8. Filippin NT et al. Quality of life of subjects with Parkinson's disease and caregivers. Fisioter. Mov. 2014: 27(1):57-66.

9. Martins-Basseto J, Zeigelboim BS, Jurkiewicz AL, Ribas A, Rosa MRD. Reabilitação Vestibular em idosos com Parkinson. Rev CEFAC. 2007; 9(2):269-81.

10. Quagliato LB, Viana MA, Barasnevicius EMAQ Simis S. Alterações do olfato na doença de Parkinson. Arq Neuro Psiquiatr. 2007;65(3-A):647-52.

11. Aires, MM. Fisiologia. $2^{\text {th }}$ ed. Rio de Janeiro: Guanabara Koogan; 1999.

12. Christofoletti G, Olian MM, Gobbi LTB, Gobbi SSF. Risco de quedas em idosos com doença de Parkinson e Alzheimer. Rev Bras Fisioter. 2006;10(4):429-33.

13. Haase DCB, Machado DC, Oliveira JGD. Atuação da fisioterapia no paciente com doença de Parkinson. Rev Fisioter Mov. Curitiba 2008;21(1):79-85.

14. Sanvito WL. Síndromes neurológicas. $3^{\text {th }}$ ed. São Paulo: Atheneu; 2008.

15. Galhardo MMAMC, Amaral AKFJ, Vieira ACC. Caracterização dos distúrbios cognitivos na doença de Parkinson. Rev CEFAC. 2009;11(2):251-7.

16. Helena GL, Quagliato EMAB, Maura VA. Dor na doença de Parkinson. Rev Neuro-Psiquiatr. 2009;67(3).

17. O’Sullivan SB, Schmitz TJ. Fisioterapia avaliação e tratamento. $4^{\text {th }}$ ed. São Paulo: Manole, 2004.

18. Gonçalves LHT, Alvarez AM, Arruda MC. Pacientes portadores da doença de Parkinson: significado de suas vivências. Rev Acta Paul Enferm. 2007;20(1):62-8.

19. Albuquerque AV. Tremor Essencial. Rev Neurocienc. 2010;(1):1-5.

20. Santos VVS, Leite MAA, Silveira R, Antoniolli R, Nascimento OJM, Freitas MRG. Fisioterapia na doença de Parkinson: uma breve revisão. Rev Bras Neurol 2010;46(1):17-25.

21. Cardoso SRX, Pereira, JS. Análise da função respiratória na doença de Parkinson. Arq Neuropsiquiatr. 2002;60(1):91-5. 
22. Goulart F, Pereira LX. Uso de escalas para avaliação da doença de Parkinson em fisioterapia. Rev Fisiot Pesq. 2005;2(1):49-56.

23. Mello MPB, Botelho ACG. Correlação das escalas de avaliação utilizadas na doença de Parkinson com aplicabilidade na fisioterapia. Rev Fisioter Mov. 2010; 23(1):121-7.

24. Pinto RASR, Borges V, Agiar PMC, Ferraz FAP, Hisatugo MKI, Ballalai H. Avaliação das atividades da vida diária dos pacientes com doença de Parkinson submetidos à cirurgia esteriotáxica. Arq NeuroPsiquiatr. 2002;60(2B).

25. Camargos ACR, Cópio FCQ, Sousa TRR, Goulart FO. Impacto da doença de Parkinson na qualidade de vida: uma revisão de literatura. Rev Bras Fisiot. 2004; 8(3):267-72.

26. Silva FS, Pabis JVCP, Alencar AG, Silva KB, NavarroPeternella FM. Evolução da doença de Parkinson e comprometimento da qualidade de vida. Rev Neurocienc. 2010;18(4):463-8.

27. Vital AP. Secção: Saúde/Qualidade de vida. Rev Park. 2001;(3):12-4.

28. Gasparim AZ, Jurkiewcz AL, Marques JMM, Santos RSS, Marcelino PCO, Junior FH. Deglutição e tosse nos diferentes graus da doença de Parkinson. Arq Int Otorrinolaringol. 2011;15(2):181-8.

29. Ferreira FD, Ferreira FMD, Heleno RB, Mella Júnior SE. Doença de Parkinson: aspectos fisiopatológicos e terapêuticos. Rev Saúde e Pesquisa. 2010;3(2):221-8.
30. Reis NL, Pereira JDAS, Oliveira TLR, Gazzola JM, Bofi TC, Carvalho AC. Evolução do equilíbrio funcional de pacientes com doença de Parkinson submetidos à fisioterapia em grupo. Rev Terapia Manual 2006; 4(16):116-9.

31. Mata FAF, Barros ALS, Lima CF. Avaliação do risco de queda em pacientes com doença de Parkinson. Rev Neurocienc. 2008;16(1):20-4.

32. Dias AED, Limongi JCP. Tratamento dos distúrbios da voz na doença de Parkinson: o método Lee Silverman. Arq Neuropsiquiatr. 2003;61(1):61-6.

33. Flores FT, Rossi AG, Schimidt PS. Avaliação do equilíbrio corporal na doença de Parkinson. Arq Intern Otorrinol. 2011;15(2).

34. Ferreira FV, Prado ALC, Cielo CA, Busanello AR. A relação da postura corporal com a prosódia na doença de Parkinson: estudo de caso. Rev CEFAC. 2007;9(3): 319-29.

35. Pinheiro GB. A fisiopatologia da atenção na doença de Parkinson. Rev Ensaios e Ciência. 2007;2(2):14-24.

Received: 11/09/2011

Recebido: 09/11/2011

Approved: 05/20/2015

Aprovado: 20/05/2015 
